\title{
First record and DNA barcode for Ocyurus chrysurus (Lutjanidae) from a coastal lagoon in the southwestern Gulf of Mexico
}

\author{
Manuel Castillo-Rivera ${ }^{1}$, Luis Guillermo Constante-Pérez ${ }^{1}$ \& Alejandra Serrato-Díaz ${ }^{2}$ \\ ${ }^{1}$ Laboratorio de Peces, Departamento de Biología, Universidad Autónoma Metropolitana \\ Unidad Iztapalapa, Ciudad de México, México \\ ${ }^{2}$ Laboratorio Divisional de Biología Molecular, Universidad Autónoma Metropolitana \\ Unidad Iztapalapa, Ciudad de México, México \\ Corresponding author: Manuel Castillo-Rivera (crma@xanum.uam.mx)
}

\begin{abstract}
A single sub-adult specimen of yellowtail snapper, Ocyurus chrysurus (Bloch, 1791) of 76.08 $\mathrm{mm}$ total long (TL) and weighing $4.38 \mathrm{~g}$, was caught on June 7, 2013 over a sandy habitat in the coastal lagoon of La Mancha, Veracruz, Mexico. The capture of $O$. chrysurus represents a first record for the lagoon and one of the few records for the estuarine systems of the southwestern Gulf of Mexico, even though this species is typical of habitats associated with coral reefs. Similarly, the reported sequence of the mitochondrial COI gene is also the first record of the species for coastal lagoons of this region. Other sequences of the same species were used to evaluate the haplotypic diversity in the western Atlantic Ocean.
\end{abstract}

Keywords: Ocyurus chrysurus; unusual record; genetic homogeneity; migration; coastal currents; GenBank database; environmental conditions

The Lutjanidae family includes about 113 species (Nelson et al., 2016), of which 14 are recognized for the southwestern Gulf of Mexico (Anderson, 2002; McEachran \& Fechhelm, 2005; McEachran, 2009). One of them, the yellowtail snapper, Ocyurus chrysurus (Bloch, 1791) is one of the most common reef fishes in the tropical Western Atlantic Ocean (WAO), which is of great importance for commercial and artisanal fisheries (Allen, 1985; Lindeman et al., 2016). This species is distributed in the western Atlantic from Massachusetts south along the USA coast, Bermuda, the Bahamas, throughout the Gulf of Mexico and the Caribbean Sea, and along the South American coast to São Paulo, Brazil. Its depth range is one to $165 \mathrm{~m}$, usually less than $70 \mathrm{~m}$ (Anderson, 2002). Adults of this species are associated with corals, while for young individuals, the seagrass beds are the most important nursery habitat. With growth, individuals move to shallow coral reef areas (McEachran \& Fechhelm, 2005; Lindeman et al., 2016).

La Mancha Lagoon is located in the Veracruz State

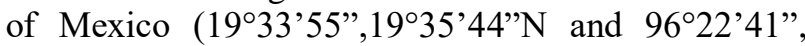
$96^{\circ} 23^{\prime} 39^{\prime \prime} \mathrm{W}$ ) in the southwestern Gulf of Mexico (Fig. 1). It is a small lagoon with a surface of $1.58 \mathrm{~km}^{2}$. At
Corresponding editor: José Gallardo

its northeastern end, this lagoon is connected to the sea via an inlet that discharges through a sand barrier. Thus, the aims of the present study were: 1 ) to report the first record of O. chrysurus in La Mancha Lagoon, and 2) to report the first sequence of the mitochondrial COI gene for the southwestern region of the Gulf of Mexico.

During the study of the fish community of the coastal lagoon of La Mancha (Veracruz, Mexico), $24 \mathrm{~h}$ sampling cycles were carried out every month from April 2012 to October 2013. Fish were collected every $2 \mathrm{~h}$ during each $24 \mathrm{~h}$ cycle, using a beach seine net (37 $\mathrm{m}$ long, $1.2 \mathrm{~m}$ deep and $1 \mathrm{~cm}$ mesh size). Immediately after their capture, fishes were anesthetized and posteriorly were fixed with $10 \%$ formalin and preserved with $70 \%$ ethanol. All biological collections were authorized and approved by the Cooperativa Pesquera La Mancha (fishermen's cooperative). In particular, O. chrysurus is not endangered or protected in Mexico, so it was not necessary to apply for any other license (SEMARNAT, 2010).

On June 7, 2013 at dawn (06:08 h), a sub-adult specimen of yellowtail snapper, Ocyurus chrysurus, of $63.0 \mathrm{~mm}$ (standard length (SL) $(76.08 \mathrm{~mm}$ total length (TL), weighing $4.38 \mathrm{~g}$ (Fig. 2), was captured at a depth 


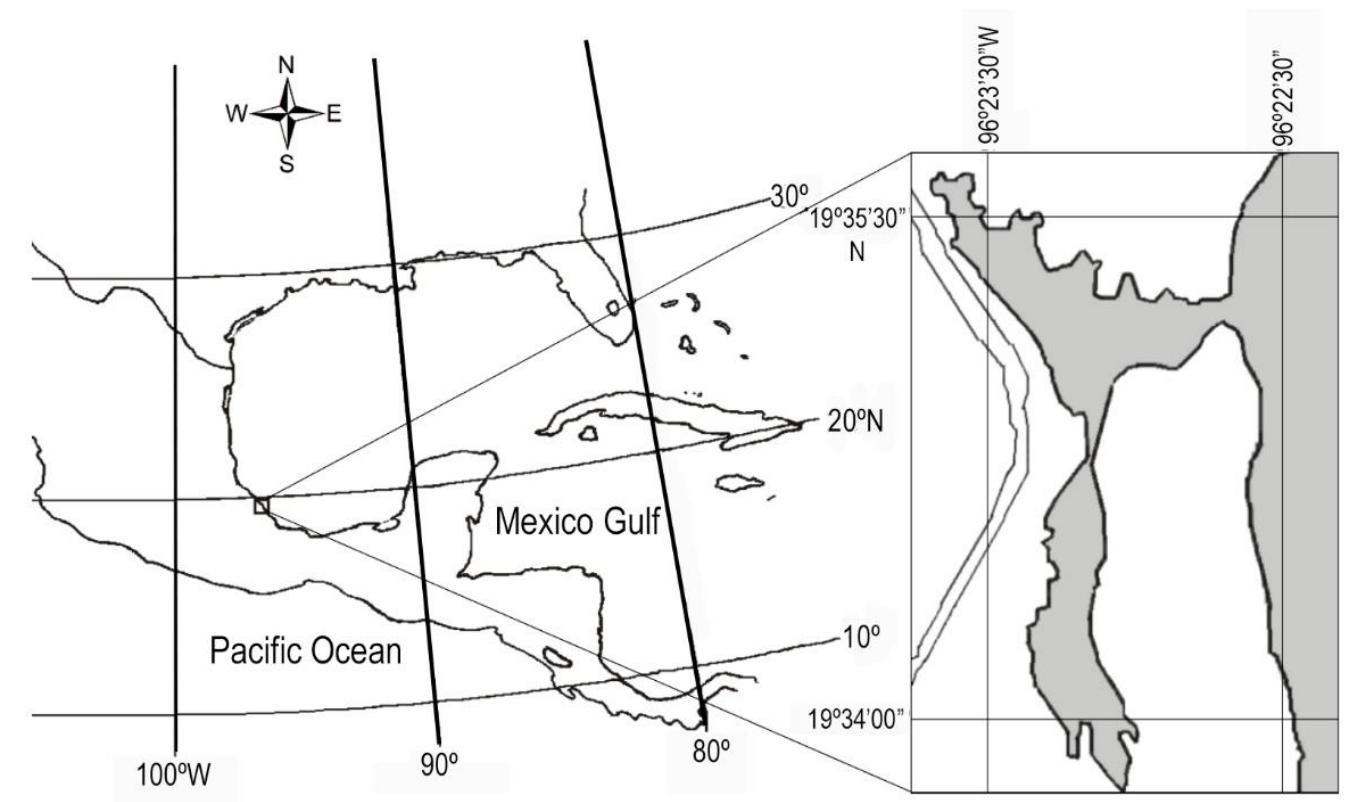

Figure 1. The geographic location of La Mancha Lagoon, Veracruz.

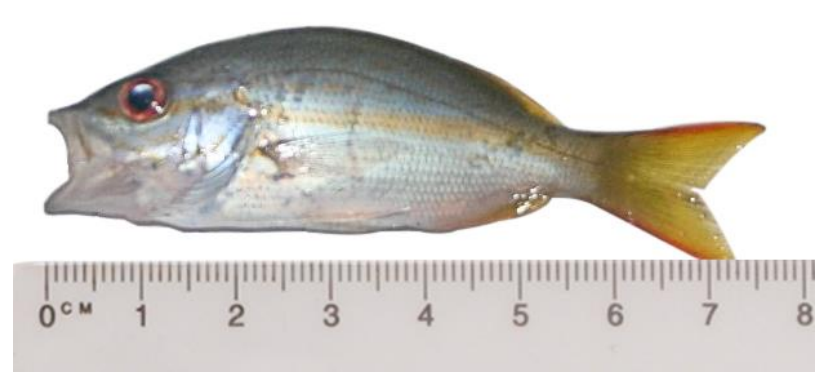

Figure 2. Yellowtail snapper, Ocyurus chrysurus (total length $=76.08 \mathrm{~mm}$ ), captured on June 7, 2013 in the coastal of La Mancha Lagoon (Veracruz, Mexico).

of $1.2 \mathrm{~m}$ over a sandy habitat inside the lagoon $\left(19^{\circ} 35^{\prime} 21^{\prime \prime} \mathrm{N}, 96^{\circ} 22^{\prime} 51^{\prime \prime} \mathrm{W}\right)$, approximately $300 \mathrm{~m}$ from the system inlet. This specimen was captured at $27.1^{\circ} \mathrm{C}$ of temperature, 37 of salinity, and $4.0 \mathrm{mg} \mathrm{L}^{-1}$ of dissolved oxygen. Measurements, counts, and color pattern of the specimen agree with those described by Allen (1985), Anderson (2002), and McEachran \& Fechhelm (2005).

Tissue samples collected from caudal fin were preserved in molecular grade $95 \%$ ethanol to validate the identity of the species. DNA was obtained with a salt extraction protocol (Lopera-Barrero et al., 2008). Partial sequence of the barcode region of the cytochrome c oxidase subunit 1 (COI) mitochondrial gene was amplified using $25 \mu \mathrm{L}$ reactions containing: $12.5 \mu \mathrm{L}$ of Go Taq Green Master Mix (PROMEGA), $0.3 \mu \mathrm{L}$ of $\mathrm{MgCl}_{2}(25 \mathrm{nM}), 1.0 \mu \mathrm{L}$ of each primer $(10$ $\mu \mathrm{M}), 9.2 \mu \mathrm{L}$ of double distilled water and $1.0 \mu \mathrm{L}$ of template DNA (50 ng $\left.\mu \mathrm{L}^{-1}\right)$. Primers used were universal: FishF1 (5'-TCAACCAACCACAAAGACA TTGGCAC-3') and FishR1 (5'-TAGACTTCTGGG TGGCCAAAG AATCA-3') (Ward et al., 2005). PCR cycling parameters consisted of denaturation of $2 \mathrm{~min}$ at $94^{\circ} \mathrm{C}$, followed by 35 cycles of $30 \mathrm{~s}$ at $94^{\circ} \mathrm{C}, 40 \mathrm{~s}$ at $52^{\circ} \mathrm{C}$ and $1 \mathrm{~min}$ at $72^{\circ} \mathrm{C}$, and a final elongation of 10 $\min$ at $72^{\circ} \mathrm{C}$. The sequencing was carried out using the Big-Dye Terminator v3.1 Sequencing kit (Applied Biosystems, USA). After the cycle sequencing reactions, unincorporated dye terminators were removed with Centrisep spin columns (Princeton Separations, Inc.). The sequencing reaction product was run on an ABI Prism 3130XL capillary sequencer (Applied Biosystems). The sequence electropherogram was edited in MEGA-X and was compared with the database of BOLD Systems.

Additional COI sequences (40) were downloaded from the GenBank database to evaluate if exists a relationship of the captured organism with other specimens distributed along the WAO. These sequences, according to 10 geographical localities, are Alabama, USA (KF461208); Florida, USA (JQ841941); Bahamas (JN021311, JQ839852, JQ839853, JQ839854); Quintana Roo, México (GU224995); Belize (GU225407, GU225408, GU225409, GU225410, GU225411, KF930198, JQ840190, JQ840191, JQ840192, JQ840193); Virgin Islands, USA (FJ998487, FJ998488, GU224985, GU224986, GU224987, GU224988, GU224989, GU224990, GU224991, GU224992, GU224993, GU224994); Curazao (JQ842255, JQ842256, JQ842257); Panama (FJ998489); Tobago Island (JQ842973); São Paulo, 

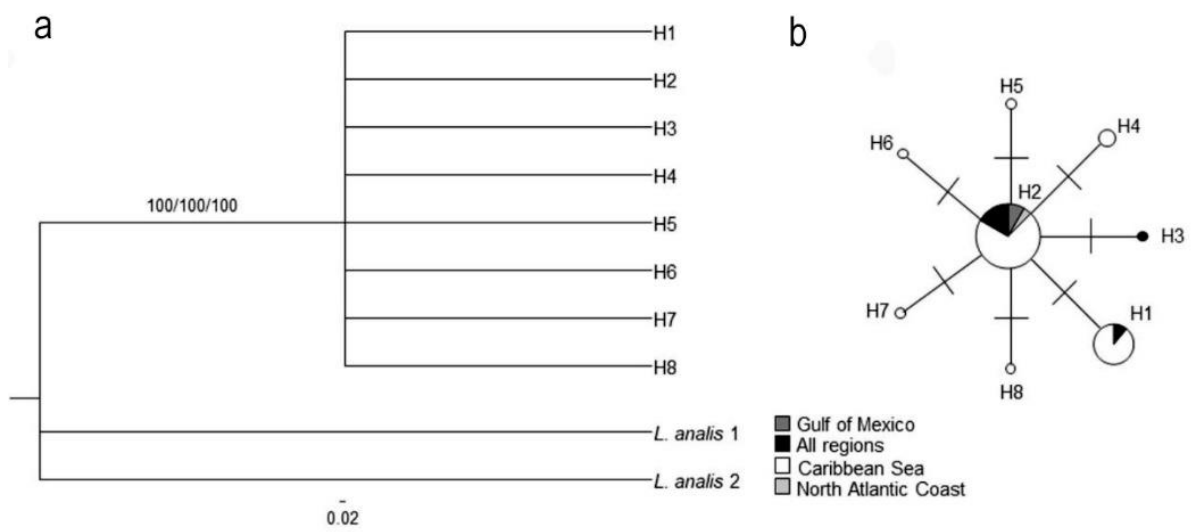

Figure 3. a) Bayesian, maximum-likelihood and neighbor-joining tree of the haplotypes identified for Ocyurus chrysurus (respective support values are shown at the nodes), with the partial sequences of the mtDNA COI gene, obtained from localities throughout Western Atlantic Ocean (WAO). H1: Bahamas, Quintana Roo, Belize, Virgin Islands, and São Paulo; H2: Alabama, Florida, Bahamas, Veracruz (present record), Belize, Panama, Virgin Islands, Curacao, Tobago, and Sao Paulo; H3: São Paulo; H4: Virgin Islands; H5: Virgin Islands; H6: Virgin Islands; H7: Virgin Islands; and H8: Bahamas. Outgroups correspond to Lutjanus analis, b) haplotype network inferred, short lines between haplotypes indicate the number of mutations occurred, and the size of circles represent the frequency of each haplotype.

Brazil (JQ365458, JQ365459, JQ365460, JQ365461, JQ365462, JQ365463); for a total of 40 sequences. According to genetic distances among lutjanid species (Chu et al., 2013; Veneza et al., 2014), the nearby species Lutjanus analis was used as an outgroup using two sequences (HQ987863, GU225352). The sequences were aligned using MEGA-X (Kumar et al., 2018). The haplotypes, haplotypic diversity and phylogenetic estimations were produced by Bayesian inference (BI), with five Markov chains, 10,000,000 generations and discarding $25 \%$ of burn-in using Mr. Bayes v.3.2 (Ronquist et al., 2012); maximum-likelihood (ML) and neighbor-joining (NJ) methods were estimated with PAUP v. 4.0b10 software (Swofford, 2002) with 1000 replicates of Bootstrap (Felsenstein, 1985). The best evolutionary method was TPM3uf +1 estimated by jModeltest v.2.1.6 using Akaike's information criteria (Posada, 2008). A haplotype network was estimated using Networks v. 4.6.1.3 (Bandelt et al., 1999) to infer the genealogical relationships between haplotypes to calculate the genetic distances among haplotypes, pairwise genetic distance values (K2P) based on COI sequences were estimated using MEGA-X.

The partial sequence of the mitochondrial COI gene produced 604 nucleotide base pairs. The comparison with the BOLD Systems database showed a probability of placement of $100 \%$ of this sequence with the species Ocyurus chrysurus. This sequence data has been submitted to the GenBank database under accession number KU314764.
Regarding the haplotype analysis, the 41 sequences of $O$. chrysurus were grouped randomly (without any geographical arrangement) into eight different haplotypes. The sequence of the present specimen was grouped into the haplotype with a greater number of sequences (H2 with 25 sequences), which included at least one sequence from nine of the 10 geographical localities considered. Considering the wide latitudinal distribution of the sequences (from Alabama to Brazil), the high similarity between the haplotypes (with genetic distances from 0.0016 to 0.0032 ) indicates the lack of genetic structure between these locations. The haplotype network also shows little genetic variation between haplotypes, with signals of population expansion (Fig. 3).

The capture of $O$. chrysurus represents a first record for the La Mancha Lagoon and one of the few records for estuarine systems in the southwestern Gulf of Mexico (Froese \& Pauly, 2019; GBIF, 2019), even though this species has been widely reported as restricted to coral reefs environments.

According to Ortiz-Lozano et al. (2013), the coral formations closest to La Mancha Lagoon is Punta Gorda $(43 \mathrm{~km})$. Thus, the catch of the specimen reported here could have been originated by a migration from the closest reefs reported. This migration could have been facilitated by following the northwestward currents predominant from May to August on the Veracruz coasts (Allende-Arandía et al., 2016), despite the fact that the acoustic tracking of five individuals of O. chrysurus near the marine reserves in Dry Tortugas, Florida, estimated an average home range of about 4.17 
$\pm 1.75 \mathrm{~km}^{2}$, with a maximum value of $10.72 \mathrm{~km}^{2}$ (Farmer \& Ault, 2011).

According to the GenBank and BOLD Systems databases, the reported sequence of the mitochondrial $\mathrm{COI}$ gene is also the first record for the species in the southwestern region of the Gulf of Mexico. The results obtained about the haplotypic diversity analysis seem to indicate that the specimens of $O$. chrysurus distributed along the WAO (from Alabama to Brazil) are genetically homogeneous, without any genetic structure, at least to the mitochondrial COI gene. In this way, the pattern of genetic homogeneity observed in $O$. chrysurus in the present study is similar to that found in other lutjanids (Da Silva et al., 2015). Even other studies that use molecular markers with a higher evolutionary rate (nuclear microsatellites and others mtDNA sequences) have provided evidence of significant, although weak genetic differences among different geographic samples of $O$. chrysurus (Saillant et al., 2012).

Studies that also use molecular markers with a high rate of change (cytochrome $b$ and mtDNA controlregion) showed no differences among $O$. chrysurus populations distributed along more than $3,000 \mathrm{~km}$ of the Brazilian coast (Vasconcellos et al., 2008; Da Silva et al., 2015). Although, these studies have also suggested restriction of gene flow between Belize (Caribbean) and Brazilian localities, the absence of sampled individuals between these two regions made it difficult to conduct more analyses on historical connectivity between populations in this geographic range (Da Silva et al., 2015). By contrast, in the present study, 32 sequences corresponding to seven localities in the Caribbean were considered (from the Bahamas to Panama and Tobago), including a southernmost record in Brazil (São Paulo).

\section{ACKNOWLEDGMENTS}

We would like to thank A. Méndez-Rodríguez for her assistance in genetic analysis and O.M. García for the edition of the figures.

\section{REFERENCES}

Allen, G.R. 1985. Snappers of the world. An annotated and illustrated catalogue of lutjanid species known to date. FAO, Roma.

Allende-Arandía, M.E., Zavala-Hidalgo, J., RomeroCenteno, R., Mateos-Jasso, A., Vargas-Hernández, J.M. \& Zamudio, L. 2016. Analysis of ocean current observations in the northern Veracruz Coral Reef System, Mexico: 2007-12. Journal of Coastal
Research, 32(1): 46-55. doi: 10.2112/JCOASTRES-D14-00148.1

Anderson, W.D. 2002. Lutjanidae. Snappers. In: Carpenter, K.E. (Ed.). The living marine resources of the western central Atlantic. FAO species identification guide for fishery purposes and American Society of Ichthyologists and Herpetologists. FAO, Rome, Special Publication, 5: 1479-1504.

Bandelt, H.J., Forster, P. \& Röhl, A. 1999. Median-joining networks for inferring intraspecific phylogenies. Molecular Biology and Evolution, 16(1): 37-48. doi: 10.1093/oxfordjournals.molbev.a026036

Chu, C., Rizman-Idid, M. \& Chong, V.C. 2013. Phylogenetic relationships of selected genera of Lutjanidae inferred from mitochondrial regions, with a note on the taxonomic status of Pinjalo pinjalo. Ciencias Marinas, 39(4): 349-361. doi: 10.7773/cm.v39i4.2287

Da Silva, R., Veneza, I., Sampaio, I., Araripe, J., Schneider, H. \& Gomes, G. 2015. High levels of genetic connectivity among populations of yellowtail snapper, Ocyurus chrysurus (Lutjanidae, Perciformes), in the western south Atlantic revealed through multilocus analysis. Plos One, 10(3): e0122173. doi: 10.1371/journal.pone.0122173

Farmer, N.A. \& Ault, J.S. 2011. Grouper and snapper movements and habitat use in Dry Tortugas, Florida. Marine Ecology Progress Series, 433: 169-184. doi: 10.3354/meps09198

Felsenstein, J. 1985. Confidence limits on phylogenies: an approach using the bootstrap. Evolution, 39(4): 783791. doi: 10.1111/j.1558-5646.1985.tb00420.x

Froese, R. \& Pauly, D. (Eds.). 2019. FishBase. World Wide Web electronic publication. [https://www.fishbase.se/search.php]. Reviewed: July 01, 2019.

Global Biodiversity Information Facility (GBIF). 2019. GBIF Home Page. [https://www.gbif.org]. Reviewed: July 01, 2019.

Kumar, S., Stecher, G., Li, M., Knyaz, C. \& Tamura, K. 2018. MEGA X: molecular evolutionary genetics analysis across computing platforms. Molecular Biology and Evolution, 35(6): 1547-1549. doi: 10.1093/ molbev/msy096

Lindeman, K., Anderson, W., Carpenter, K.E., Claro, R., Cowan, J., Padovani-Ferreira, B., Rocha, L.A., Sedberry, G. \& Zapp-Sluis, M. 2016. Ocyurus chrysurus. The IUCN red list of threatened species. doi: 10.2305/IUCN.UK.2016-1.RLTS.T194341A231 6114.en

Lopera-Barrero, N.M., Povh, J.A., Riberiro, R.P., Gomes, P.C., Jacometo, C.B. \& Lopes, T.S. 2008. Comparación de protocolos de extracción de $\mathrm{ADN}$ con muestras de aleta y larva de peces: extracción modifi- 
cada con cloruro de sodio. Ciencia e Investigación Agraria, 35(1): 77-86. doi: 10.4067/S0718-162020080 00100008

McEachran, J.D. 2009. Fishes (Vertebrata: Pisces) of the Gulf of Mexico. In: Felder, D.L. \& Camp, D.K. (Eds.). Gulf of Mexico - origins, waters, and biota. Biodiversity. Texas A\&M University Press, Texas, pp. 1223-1316.

McEachran, J.D. \& Fechhelm, J.D. 2005. Fishes of the Gulf of Mexico: Scorpaeniformes to Tetraodontiformes. University of Texas Press, Texas.

Nelson, J.F., Grande, T.C. \& Wilson, M.V.H. 2016. Fishes of the world. Wiley, New Jersey.

Ortiz-Lozano, L., Pérez-España, H., Granados-Barba, A., González-Gándara, C., Gutiérrez-Velázquez, A. \& Martos, J. 2013. The reef corridor of the southwest Gulf of Mexico: challenges for its management and conservation. Ocean \& Coastal Management, 86: 2232. doi: 10.1016/j.ocecoaman.2013.10.006

Posada, D. 2008. jModelTest: phylogenetic model averaging. Molecular Biology and Evolution, 25(7): 1253-1256. doi: 10.1093/molbev/msn083

Ronquist, F., Teslenko, M., van der Mark, P., Ayres, D.L., Darling, A., Höhna, S., Larget, B., Liu, B., Suchard, M.A. \& Huelsenbeck, J.P. 2012. Mr. Bayes 3.2: efficient Bayesian phylogenetic inference and model choice across a large model space. Software for Systematics and Evolution, 61(3): 530-542. doi: 10.1093/sysbio/sys029

Saillant, E.A., Rensaw, M.A., Cummings, N.J. \& Gold, J.R. 2012. Conservation genetics and management of yellowtail snapper, Ocyurus chrysurus, in the US Caribbean and South Florida. Fisheries Management and Ecology, 19(4): 301-312. doi: 10.1111/j.13652400.2011.00840.x

Received: 23 July 2019; Accepted: 27 December 2019
Secretaría de Medio Ambiente y Recursos Naturales (SEMARNAT). 2010. Norma Oficial Mexicana NOM-059-SEMARNAT-2010. Protección ambiental - especies nativas de México de flora y fauna silvestres - categorías de riesgo y especificaciones para su inclusión, exclusión o cambio - lista de especies en riesgo. Diario Oficial de la Federación, 30 diciembre 2010.

Swofford, D.L. 2002. PAUP: phylogenetic analysis using parsimony (and other methods), Version 4.0 Beta 10. Sinauer Associates, Sunderland. doi: 10.1111/j.00143820.2002.tb00191.x

Vasconcellos, A.V., Vianna, P., Paiva, P.C., Schama, R. \& Solé-Cava, A. 2008. Genetic and morphometric differences between yellowtail snapper (Ocyurus chrysurus, Lutjanidae) populations of the tropical west Atlantic. Genetics and Molecular Biology, 31: 308316. doi: 10.1590/S1415-47572008000200026

Veneza, I., Felipe, B., Oliveira, J., Silva, R., Sampaio, I., Schneider, H. \& Gomes, G. 2014. A barcode for the authentication of the snappers (Lutjanidae) of the western Atlantic: rDNA 5S or mitochondrial COI? Food Control, 38: 116-123. doi: 10.1016/j.foodcont. 2013.10.012

Ward, R.D., Zemlak, T.S., Innes, B.H., Last, P.R. \& Hebert, P.D.N. 2005. DNA barcoding Australia's fish species. Philosophical Transactions of the Royal Society, 360(1462): 1847-1857. doi: 10.1098/rstb. 2005.1716 